\title{
Genotypic variability of pigeonpea in distribution of photosynthetic carbon at low phosphorus level
}

\author{
Kounosuke Fujita ${ }^{\mathrm{a}, *}$, Yoshito Kai ${ }^{\mathrm{a}}$, Miki Takayanagi ${ }^{\mathrm{a}}$, Hany El-Shemy ${ }^{\mathrm{a}}$, \\ Joseph J. Adu-Gyamfi ${ }^{\mathrm{b}}$, Pravat K. Mohapatra ${ }^{\mathrm{c}}$ \\ ${ }^{a}$ Graduate School of Biosphere Science, Hiroshima University, 1-4-4 Kagamiyama, Higashi-Hiroshima 739-8528, Japan \\ b ICRISAT-Nigeria, C/O IITA, PMB 5320, Ibadan, Nigeria \\ ${ }^{\mathrm{c}}$ School of Life Science, Sambalpur University, Jyoti Vihar, Sambalpur 768019, India
}

Received 17 January 2003; received in revised form 16 September 2003; accepted 15 October 2003

\begin{abstract}
Pigeonpea (Cajanus cajan L. Millsp.) is an important grain protein crop, which thrives in the P-deficient soils of tropical and subtropical Asia. The varietal differences in soil phosphorus uptake and partitioning of the crop are well documented, but the mechanism of carbon distribution between the source and sink at low P supply is not understood. In the present study, the effect of a low P supply on the distribution of photosynthetic carbon of one high-yielding improved hybrid cultivar, ICPH 8 and two low-yielding non-hybrid cultivars, ICPL 87 and UPAS 120, were compared by feeding the plants ${ }^{13} \mathrm{CO}_{2}$ at the vegetative and reproductive stages of development. A low P supply significantly decreased plant biomass, $\mathrm{P}$ uptake, average leaf area and photosynthetic activity of all genotypes; the decrease was smallest in ICPH 8 and largest in UPAS 120. ICPH 8 retained more plant biomass at low P supply due to higher P-absorption capacity rather than high P-utilization efficiency. The tolerance of ICPH 8 to low P is mostly related to its maintenance of a high leaf area and rate of photosynthesis. In contrast, $\mathrm{P}$ deficiency severely reduced leaf initiation of the sensitive cultivar UPAS 120, and reduced its photosynthesis. Under limiting P supply, partitioning of ${ }^{13} \mathrm{C}$ increased in favor of the roots in all cultivars, but the resistant cultivar ICPH 8 partitioned less ${ }^{13} \mathrm{C}$ to roots, and invested more in shoot growth compared to the non-hybrid cultivars. Similarly, partitioning of ${ }^{13} \mathrm{C}$ to the raceme was greater in ICPL 87 than in the highly sensitive UPAS 120. It is concluded that P deficiency affects primarily sink activity by restricting cellulose biosynthesis in the meristematic sink cells.
\end{abstract}

(C) 2003 Elsevier Ireland Ltd. All rights reserved.

Keywords: Low phosphorus supply; Pigeonpea; Photosynthetic carbon

\section{Introduction}

Pigeonpea (Cajanus cajan L. Millsp.) is a tropical and subtropical leguminous crop used extensively as a substitute for expensive animal protein in developing countries. The crop is tolerant to low P supply and acid soils [1] and grows well in the P-deficient soils of the tropical environment. The plant possesses a high capacity for incorporation of external $\mathrm{P}$ into organic $\mathrm{P}$, and its critical requirement of $\mathrm{P}$ concentration for dry matter production is low compared to other major protein crops like soybean (Glycine max L.) [2]. Variation in P-utilization efficiency also exists among cultivars

\footnotetext{
Abbreviations: $\mathrm{P}$, phosphorus

* Corresponding author. Tel.: +81-824-24-7963; fax: +81-824-24-0791.

E-mail address: fujiko@hiroshima-u.ac.jp (K. Fujita).
}

of pigeonpea; the efficient cultivars absorb more $\mathrm{P}$ from the soil under limiting conditions, and obtain high yield through effective translocation of the absorbed $\mathrm{P}$ to the leaves [3] for photosynthesis. A plant susceptible to $\mathrm{P}$ deficiency reduces $\mathrm{CO}_{2}$ assimilation due to a decrease in RuBP pool size [4-6]. In addition, deficiency of phosphate can inhibit the functioning of the phosphate translocator in the chloroplast membrane which exchanges triose phosphate produced in the Calvin cycle within the organelle with phosphate in the cytosol; the decline of the phosphate concentration in the stroma limits photophosphorylation and photosynthesis, resulting in accumulation of glycerate-3-P [7]. The subsequent increase in the ratio of glycerate-3-P: phosphate in the chloroplast stimulates ADP glucose pyrophosphorylase, resulting in increased starch synthesis $[8,9]$. In the process, the sucrose synthesis pathway is deprived of its carbon source, i.e. triose phosphates, and partitioning of assimilates to sinks 
are reduced. Thus, any effect on growth or yield of a crop due to $\mathrm{P}$ deficiency is apparently an effect of the stress on source activity.

However, the effect of P deficiency on sink activity and its consequences on assimilate partitioning has not been studied in any detail. It is reported that $\mathrm{P}$ deficiency can affect cell division in growing tissues, and restrict expansion growth of organs [10], increase ABA translocation in the xylem [11], and reduce translocation of nitrate to sink organs in the xylem [12]. Such findings suggest direct effects of $P$ deficiency on sinks. Several $C_{3}$ and $C_{4}$ plants differ in both growth and photosynthesis responses to low $\mathrm{P}$ stress [13] as the effect of low $\mathrm{P}$ on sink activity precedes that on the source. Low sink strength at suboptimal $P$ supply can impose an end-product limitation on photosynthesis [6]. Although there is substantial interaction between source and sink for allocation of assimilates at low level of P supply, screening for resistance has not been assessed between cultivars. As pigeonpea has a low requirement for $\mathrm{P}$ in general, an experiment on three short-duration cultivars that differ in yield was designed to study the response of the cultivars to P deficiency on translocation and distribution of photosynthetic carbon between source and sink organs. The cultivars included ICPH 8, which is the world's first pigeonpea hybrid, and two non-hybrids, namely ICPL 87 and UPAS 120; the hybrid cultivar has a grain yield advantage of 20 and $30 \%$, over the non-hybrids ICPL 87 and UPAS 120, respectively [14].

\section{Materials and methods}

\subsection{Plant material}

Three pigeonpea (C. cajan L. Millsp.) cultivars, ICPH 8, ICPL 87 and UPAS 120 were obtained from ICRISAT, Patancheru, India. All three are short-duration cultivars maturing in 120-130 days. The hybrid cultivar ICPH 8 possesses superiority in crop growth rate, biomass production and drought resistance compared to the non-hybrids, ICPL 87 and UPAS 120. Two experiments were conducted by growing the plants in pots. In the first experiment all three cultivars were used, whereas ICPH 8 was excluded from the second experiment. The pots contained granite regosol with a basal dressings of 1.50 and $1.39 \mathrm{~g} \mathrm{~N}$ per pot at the times of planting and at flowering, respectively. The soil $\mathrm{pH}$ was adjusted to 6.5. Each pot contained three plants. The pots were kept inside a vinyl house under natural light conditions during April to September in all the experiments with a temperature range of $30-40^{\circ} \mathrm{C}$.

\subsection{Experiment I}

The three genotypes were grown at both control $\mathrm{P}$ $(2.50 \mathrm{~g} \mathrm{P}$ per pot $)$ and low $\mathrm{P}(0.05 \mathrm{~g} \mathrm{P}$ per pot $)$ in three replicates arranged in a randomized complete block design.

\subsection{Analyses of phosphorus and carbohydrate contents}

At 78 days after planting one plant from each pot was sampled and separated into leaves, stem of the upper five leaves, residual part of the stem, and roots. The leaf number was counted and leaf area was determined with a leaf area meter (model AAM-5, Hayashi Denko Co. Ltd., Japan). The plant material was dried in an open air oven for 3 days.

Ground plant parts were digested in a mixture of concentrated sulphuric and nitric acids and $\mathrm{P}$ content was determined by the molybdenum blue method [1]. Stem and root samples were additionally used to determine the sugar and starch contents by the anthrone sulphuric acid method [15]. The soluble fraction was extracted with boiling $80 \%$ aqueous ethanol, and the residue with $600 \mathrm{~g} \mathrm{l}^{-1} \mathrm{HClO}_{4}$, corresponding to the sugar and starch fractions, respectively.

\subsection{Photosynthetic rate}

The photosynthetic rate of leaves of intact plants was measured on day 78 with a portable infra red gas analyzer (model Li-6200, Li-Cor Inc., Lincoln, NE, USA). The photosynthetically active radiation (PAR) was more than $1700 \mu \mathrm{mol} \mathrm{m}^{-2} \mathrm{~s}^{-1}$, and the $\mathrm{CO}_{2}$ concentration of the air was $380-420 \mu 11^{-1}$. The photosynthetic rate of the second and third trifoliate leaves from the top of all cultivars were measured between 10:00 and 12:00 $\mathrm{h}$.

\section{5. ${ }^{13} \mathrm{CO}_{2}$ feeding}

${ }^{13} \mathrm{CO}_{2}$ feeding was conducted on day 78 in order to determine the partitioning of labelled assimilates in various plant parts by the method of Sawada et al. [16]. The fifth leaf from the top was enclosed in a transparent plastic bag to which a gas balanced with air $\left(\mathrm{O}_{2}\right.$ and $\left.\mathrm{N}_{2}\right)$ containing ${ }^{13} \mathrm{CO}_{2}\left(99.5\right.$ at. $\left.\%{ }^{13} \mathrm{C}\right)$ was injected. The concentration of the gas mixture inside the cylinder was $36 \mathrm{~Pa}$. The leaf was allowed to assimilate ${ }^{13} \mathrm{CO}_{2}$ under natural light conditions for $2 \mathrm{~h}$. During ${ }^{13} \mathrm{CO}_{2}$ assimilation, the PAR was above $1700 \mu \mathrm{mol} \mathrm{m}^{-2} \mathrm{~s}^{-1}$. The plants were harvested 3 days after ${ }^{13} \mathrm{CO}_{2}$ assimilation. The plants were separated into the ${ }^{13} \mathrm{CO}_{2}$-fed leaf, leaves above the fed leaf, stem above the fed leaf, stem and leaves below the fed leaf, and roots. The plant parts were dried in an open air oven at $70^{\circ} \mathrm{C}$, weighed and ground to powder in a vibrating sample mill (model T1-100, Heiko Co., Japan).

\subsection{Experiment II}

In this experiment, the two non-hybrid cultivars ICPL 87 and UPAS 120 were grown in pots at two levels of phosphorus, i.e. control $\mathrm{P}\left(100 \mathrm{~kg} \mathrm{Pha}^{-1}\right)$ and low $\mathrm{P}\left(10 \mathrm{~kg} \mathrm{Pha}^{-1}\right)$. At 135 days after planting, ${ }^{13} \mathrm{CO}_{2}$ was fed to the plants in a manner similar to experiment I in order to find out allocation of labelled assimilates in the cell components of the flowering inflorescence. The plants were harvested 3 days 
after the ${ }^{13} \mathrm{CO}_{2}$ feeding in the manner described above. The raceme on the axil of the fed leaf was collected separately and frozen in liquid nitrogen and preserved at $-80^{\circ} \mathrm{C}$ until analysis.

\subsection{Fractionation and measurement of sugars in each fraction}

The raceme was freeze-dried for estimation of dry weight and ground to a powder. An aliquot of the sample was taken for fractionation of the cell wall according to the method of Sakurai et al. [17]. The sample was boiled in methanol for $10 \mathrm{~min}$. The extract contained the methanol-soluble sugars. The methanol-insoluble residue was freeze dried for estimation of weight. The material was homogenized in liquid nitrogen before addition of deionised water. The homogenate was centrifuged at $1000 \times g$ for $10 \mathrm{~min}$. The supernatant was used for estimation of water-soluble sugars, and the residue was processed for estimation of cell components. Before estimation of water soluble sugars, aqueous TCA (5\%, w/v) was added to the supernatant for precipitation of soluble protein. The protein was discarded after centrifugation, and the supernatant was used for sugar analysis. The residue containing cell walls was further washed with deionised water, acetone and a mixture of methanol and chloroform (1:1, $\mathrm{v} / \mathrm{v})$ for removal of fats. The material was dried in air and treated with 2 units $\mathrm{ml}^{-1}$ of porcine pancreatic $\alpha$-amylase (type 1-A, Sigma, St. Louis, USA) in Na-acetate buffer (pH $6.5,50 \mathrm{mM}$ ) for $2 \mathrm{~h}$ for removal of starch. Protein was removed by treatment with $200 \mathrm{mg} \mathrm{ml}^{-1}$ pronase (Actinase Kaken Kakagu Co., Tokyo, Japan) in sodium phosphate buffer ( $\mathrm{pH} 6.5,50 \mathrm{mM})$ containing $5 \%(\mathrm{v} / \mathrm{v})$ aqueous ethanol for $18 \mathrm{~h}$. The pectic fraction was extracted from the residue by addition of $50 \mathrm{mM}$ EDTA at $95^{\circ} \mathrm{C}$ for $15 \mathrm{~min}$. Thereafter the residue was treated with a solution of $17.5 \%(\mathrm{w} / \mathrm{v})$ $\mathrm{NaOH}$ containing $0.02 \%$ (w/v) $\mathrm{NaBH}_{4}$ for $18 \mathrm{~h}$ for the extraction of hemicellulose. The insoluble material remaining after this extraction was designated as cellulose.

\section{8. ${ }^{13} \mathrm{C}$ analysis}

The ${ }^{13} \mathrm{C}$ abundance in the ground plant material or different fractions was determined with a mass spectrometer model Delta Plus (Finnigan Co., San Jose, USA). The ${ }^{13} \mathrm{C}$ atom percentage excess in the plant sample was calculated as the difference in ${ }^{13} \mathrm{C}$ atom percentage between the sample and a standard of pure chemical glycine. The amount of labelled $\mathrm{C}$ in the plant sample was calculated according to the method used by Sawada et al. [16].

\section{Results}

\subsection{Experiment I}

\subsubsection{Biomass production and leaf area expansion}

Total leaf area, number of leaves and average leaf area were lower at low $\mathrm{P}$ supply than at control $\mathrm{P}$ in all three genotypes during the vegetative stage of growth (Table 1). Phosphorus deficiency also reduced the dry weight of the plant significantly, because of its adverse effect on shoot growth; the root growth was not significantly affected. The improved cultivar ICPH 8 was less affected by P deficiency than the non-hybrids.

\subsubsection{Phosphorus uptake and partitioning}

The improved hybrid ICPH 8 had a larger total P content per plant than the non-hybrid cultivars (Table 1). The cultivar UPAS 120 was the poorest of the three in accumulating total $\mathrm{P}$; it accumulated nearly half of the amount of that in ICPH 8. At low P supply, the same trend of $\mathrm{P}$ accumulation was maintained among the cultivars; the decline in $\mathrm{P}$ content per plant was higher in the non-hybrids than in the hybrid cultivar. Similar to the total plant $\mathrm{P}$, the uptake of $\mathrm{P}$ by the roots declined drastically at low P. However, the proportion of $\mathrm{P}$ in the roots increased when the cultivars were grown at low $\mathrm{P}$ (Fig. 1). The difference in proportion of $\mathrm{P}$ in the roots

Table 1

Effect of phosphorus treatment on leaf area and biomass of three pigeonpea genotypes at 78 days after planting

\begin{tabular}{|c|c|c|c|c|c|c|c|}
\hline \multirow[t]{2}{*}{ Plant part } & \multicolumn{2}{|l|}{ ICPH 8} & \multicolumn{2}{|l|}{ ICPL 87} & \multicolumn{2}{|l|}{ UPAS 120} & \multirow[t]{2}{*}{$\operatorname{LSD}(0.05)$} \\
\hline & Control & Low P & Control & Low P & Control & Low P & \\
\hline Leaf area $\left(\mathrm{m}^{2}\right.$ per plant $)$ & $0.86(100)$ & $0.46(54)$ & $0.71(100)$ & $0.2(29)$ & $0.67(100)$ & $0.16(23)$ & 0.13 \\
\hline Number of leaves (number per plant) & 17 & 12 & 15 & 6 & 11 & 9 & 1.6 \\
\hline Average leaf area (m² per leaf) & 0.051 & 0.039 & 0.047 & 0.034 & 0.061 & 0.017 & 0.011 \\
\hline Leaf mass per unit area $\left(\mathrm{kg} \mathrm{DW} \mathrm{m}^{-2}\right)$ & 256 & 313 & 329 & 423 & 367 & 391 & 96 \\
\hline \multicolumn{8}{|l|}{ Dry weight (g per plant) } \\
\hline Shoots & 4.52 & 2.50 & 4.26 & 1.44 & 4.62 & 0.99 & 2.2 \\
\hline Roots & 0.98 & 1.04 & 1.40 & 0.74 & 1.38 & 0.51 & $\mathrm{NS}^{\mathrm{a}}$ \\
\hline Whole plant & 5.50 & $3.54(64)$ & 5.66 & $2.18(30)$ & 6.00 & $1.50(25)$ & 2.89 \\
\hline $\mathrm{P}$ content (mg per plant) & $23.99(100)$ & $6.84(29)$ & $17.26(100)$ & $2.75(16)$ & $13.67(100)$ & $2.22(16)$ & 2.57 \\
\hline P uptake $\left(\mathrm{mg} \mathrm{g}^{-1}\right.$ root DW) & $24.3(100)$ & $6.6(27)$ & $12.3(100)$ & $3.7(30)$ & $9.9(100)$ & $4.4(44)$ & 3.46 \\
\hline $\mathrm{P}$ use efficiency $\left(\mathrm{g} \mathrm{DW} \mathrm{mg}^{-1} \mathrm{P}\right)$ & 0.229 & 0.518 & 0.328 & 0.793 & 0.439 & 0.676 & 0.193 \\
\hline
\end{tabular}

The values in parentheses indicate values in percent of control treatment.

a NS, non-significant. 


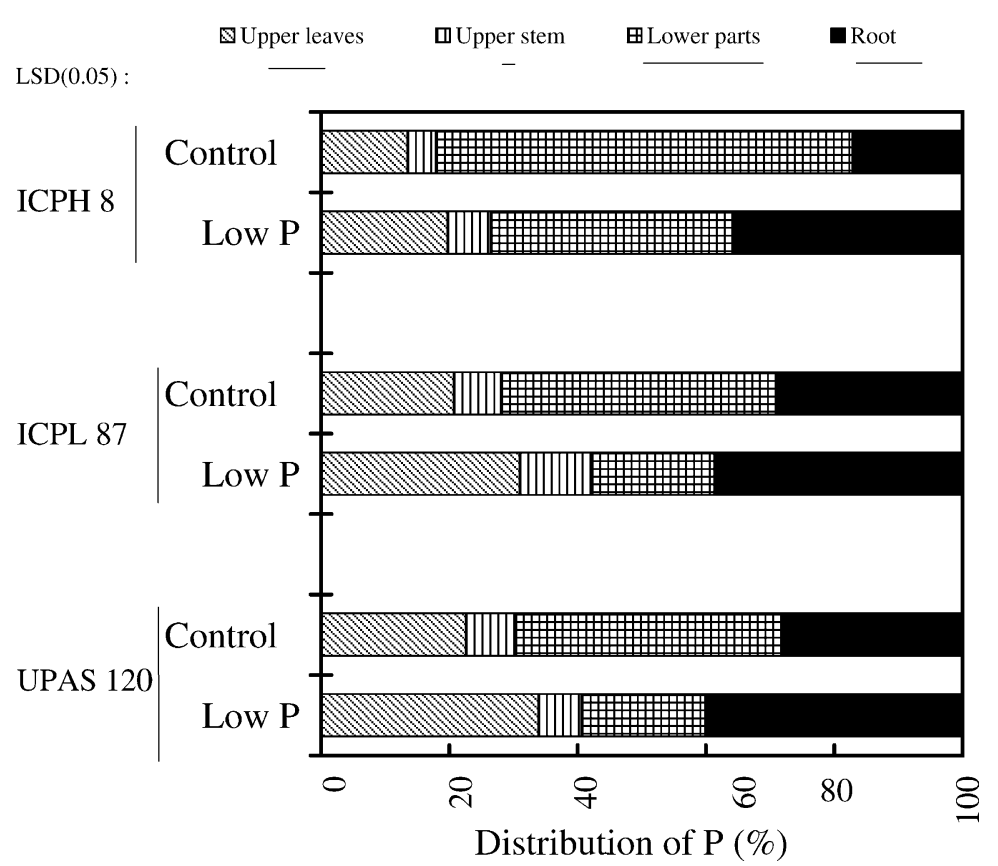

Fig. 1. Effect of phosphorus (P) application levels on partitioning of $\mathrm{P}$ to various plant parts of pigeonpea cultivars at the vegetative growth stage (Experiment I).

at low $\mathrm{P}$ among the cultivars was not significant. Among the shoot parts, the partitioning of $\mathrm{P}$ to the upper leaves increased at low P supply at the cost of the lower parts of the shoot. At control P, partitioning of $\mathrm{P}$ occurred in favour of the lower part of the shoot, and it was maximum in ICPH 8.

The concentration of $\mathrm{P}$ in different plant organs of ICPH 8 was higher than that in the other two cultivars at control $\mathrm{P}$ (Table 2). However, at low $\mathrm{P}$, the concentration of $\mathrm{P}$ in the upper part of the plant was either equal to or higher in the non-hybrids than in the hybrid cultivar ICPH 8 . At low $\mathrm{P}$ supply, the concentration of $\mathrm{P}$ in the lower part of the shoot and roots in the non-hybrid cultivars was lower than that of the hybrid cultivar.

\subsubsection{Photosynthetic rate}

The photosynthetic rate declined in low $\mathrm{P}$ for all the three cultivars, but the effect was more pronounced in the nonhybrids than in the improved hybrid (Table 3 ). The reduction of stomatal conductance and leaf internal $\mathrm{CO}_{2}$ concentration were higher in the non-hybrids than in the hybrid cultivar.

Table 2

Effect of phosphorus treatment on the P concentration and content per plant in three pigeonpea genotypes at 78 days after planting

\begin{tabular}{|c|c|c|c|c|c|c|}
\hline \multicolumn{2}{|l|}{ ICPH 8} & \multicolumn{2}{|c|}{ ICPL 87} & \multicolumn{2}{|c|}{ UPAS 120} & \multirow[t]{2}{*}{$\operatorname{LSD}(0.05)$} \\
\hline Control & Low $\mathrm{P}$ & Control & Low $\mathrm{P}$ & Control & Low $\mathrm{P}$ & \\
\hline \multicolumn{7}{|c|}{ Upper leaves ( $\mathrm{g} \mathrm{kg}^{-1} \mathrm{DW} \mathrm{mg}$ per plant) } \\
\hline 6.08 & 1.82 & 3.91 & 1.87 & 4.11 & 1.86 & 0.106 \\
\hline 3.20 & 1.35 & 3.57 & 0.85 & 3.08 & 0.75 & 0.097 \\
\hline \multicolumn{7}{|c|}{ Upper stem ( $\mathrm{g} \mathrm{kg}^{-1} \mathrm{DW} \mathrm{mg}$ per plant $)$} \\
\hline 4.58 & 1.86 & 3.25 & 1.72 & 2.60 & 2.51 & 0.095 \\
\hline 1.06 & 0.46 & 1.27 & 0.31 & 1.05 & 0.33 & 0.054 \\
\hline \multicolumn{7}{|c|}{ A matured leaf at the lower parts $\left(\mathrm{g} \mathrm{kg}^{-1} \mathrm{DW} \mathrm{mg}\right.$ per plant $)$} \\
\hline 5.78 & 2.06 & 3.62 & 1.11 & 3.48 & 1.19 & 0.119 \\
\hline 0.67 & 0.34 & 0.59 & 0.13 & 0.64 & 0.11 & 0.020 \\
\hline \multicolumn{7}{|c|}{ Lower leaves and stem $\left(\mathrm{g} \mathrm{kg}^{-1} \mathrm{DW} \mathrm{mg}\right.$ per plant $)$} \\
\hline 4.17 & 1.58 & 2.57 & 0.59 & 2.14 & 0.79 & 0.070 \\
\hline 15.46 & 2.59 & 7.41 & 0.53 & 5.69 & 0.42 & 0.293 \\
\hline \multicolumn{7}{|c|}{ Roots ( $\mathrm{g} \mathrm{kg}^{-1} \mathrm{DW}$ mg per plant) } \\
\hline 4.01 & 2.40 & 2.97 & 1.46 & 2.87 & 1.76 & 0.065 \\
\hline 3.93 & 2.50 & 4.16 & 1.08 & 3.96 & 0.90 & 0.212 \\
\hline
\end{tabular}


Table 3

Effect of phosphorus treatment on rate of photosynthesis, stomatal conductance, leaf internal $\mathrm{CO}_{2}$ concentration, and transpiration of pigeonpea genotypes

\begin{tabular}{|c|c|c|c|c|c|}
\hline \multicolumn{2}{|l|}{ ICPH 8} & \multicolumn{2}{|l|}{ ICPL 87} & \multicolumn{2}{|c|}{ UPAS 120} \\
\hline Control & Low P & Control & Low $\mathrm{P}$ & Control & Low P \\
\hline \multicolumn{6}{|c|}{ Photosynthesis rate $\left(\mu \mathrm{mol} \mathrm{CO} \mathrm{Cm}^{-2} \mathrm{~s}^{-1}\right)$} \\
\hline 13.9 & $8.8^{*}$ & 11.7 & $6.6^{*}$ & 10.9 & $6.1^{*}$ \\
\hline \multicolumn{6}{|c|}{ Stomatal conductance ( $\mathrm{mol} \mathrm{H}_{2} \mathrm{O} \mathrm{m}^{-2} \mathrm{~s}^{-1}$ ) } \\
\hline 0.155 & $0.135 \mathrm{NS}^{\mathrm{a}}$ & 0.214 & $0.088 \mathrm{NS}^{\mathrm{a}}$ & 0.212 & $0.057^{*}$ \\
\hline \multicolumn{6}{|c|}{ Leaf internal $\mathrm{CO}_{2}$ concentration $\left(\mu \mathrm{CO}_{2} \mathrm{l}^{-1}\right)$} \\
\hline 183 & $221 \mathrm{NS}^{\mathrm{a}}$ & 247 & $190 \mathrm{NS}^{\mathrm{a}}$ & 254 & $164^{*}$ \\
\hline \multicolumn{6}{|c|}{ Transpiration $\left(\mathrm{mmol} \mathrm{H}_{2} \mathrm{O} \mathrm{m}^{-2} \mathrm{~s}^{-1}\right)$} \\
\hline 2.5 & $2.4 \mathrm{NS}^{\mathrm{a}}$ & 3.4 & $1.7^{*}$ & 3.7 & $1.2^{*}$ \\
\hline
\end{tabular}

${ }^{\text {a }}$ NS, not significant.

* Significant at $P=0.05$.

\subsubsection{Sugar and starch concentrations}

The starch and sugar concentrations of the upper part of the stem of the cultivars did not vary significantly at control $\mathrm{P}$, but the concentration of sugar in the roots was higher in the hybrid genotype than in the non-hybrids (Table 4). The roots of the non-hybrid cultivars had higher concentration of starch than the hybrid cultivar. Phosphorus deficiency decreased sugar and starch concentrations in the upper part of the stem, but the effect was not significant in UPAS 120. Similarly, P deficiency decreased sugar concentration in the roots of ICPH 8 and ICPL 87, but not in UPAS 120. The effect of $\mathrm{P}$ deficiency on the starch concentration of the roots was different from that of sugar; the concentration remained mostly similar at both levels of $\mathrm{P}$.

\section{2. ${ }^{13} \mathrm{C}$ partitioning among various plant parts}

The ${ }^{13} \mathrm{C}$ accumulated in plant organs was higher in the non-hybrids than in the improved hybrid except for the lower shoot parts of UPAS 120 at control P (Table 5). At control P, the amount of ${ }^{13} \mathrm{C}$ in the roots was lower than in other organs in all the cultivars. At low $\mathrm{P},{ }^{13} \mathrm{C}$ accumulation increased in the roots of all three cultivars and shoot organs of only ICPH 8 ; in the non-hybrid cultivars the amount of ${ }^{13} \mathrm{C}$ decreased in the shoot parts. The ${ }^{13} \mathrm{C}$ export rate was almost identical in all cultivars at control $\mathrm{P}$, but at low $\mathrm{P}$ it increased only in the non-hybrids. The partitioning of ${ }^{13} \mathrm{C}$ to upper leaves was greater than that to the roots at high $\mathrm{P}$ in all cultivars (Fig. 2). At low $\mathrm{P}$ the situation was just the opposite. ${ }^{13} \mathrm{C}$ partitioning increased in favor of the roots at the cost of the upper leaves; in contrast to the hybrid, the non-hybrids partitioned more ${ }^{13} \mathrm{C}$ to the roots at low $\mathrm{P}$.

\subsection{Experiment II}

\subsubsection{Plant growth and $P$ accumulation}

The whole plant weight as well as the weight of all organs was significantly reduced at low $\mathrm{P}$ supply in both the non-hybrid cultivars UPAS 120 and ICPL 87 (Table 6). The total $\mathrm{P}$ content of the plant parts was also similarly affected by low P. However, compared with ICPL 87, the effect of low P supply was more pronounced on the dry weight and total $\mathrm{P}$ content in UPAS 120. The concentration of $\mathrm{P}$ in the raceme was higher than in other organs in both cultivars. At low $\mathrm{P}$, the phosphorus concentration and dry weight of this organ were less affected than those of other parts.

\subsection{2. ${ }^{13} \mathrm{C}$ partitioning into various plant parts}

The ${ }^{13} \mathrm{C}$ atom percentage excess in the raceme was higher than in the other organs in both cultivars. At low $\mathrm{P}$, it decreased in the raceme of UPAS 120, but not in ICPL 87 (data not shown). When the leaf was fed with ${ }^{13} \mathrm{C}, 60-90 \%$

Table 4

Effect of phosphorus treatment on sugar and starch concentration in upper leaves and roots of three pigeonpea genotypes at 78 days after planting

\begin{tabular}{|c|c|c|c|c|c|c|c|}
\hline & \multicolumn{2}{|l|}{ ICPH 8} & \multicolumn{2}{|c|}{ ICPL 87} & \multicolumn{2}{|c|}{ UPAS 120} & \multirow[t]{2}{*}{$\operatorname{LSD}(0.05)$} \\
\hline & Control & Low $\mathrm{P}$ & Control & Low $\mathrm{P}$ & Control & Low $\mathrm{P}$ & \\
\hline \multicolumn{8}{|c|}{$\begin{array}{l}\text { Sugar concentration }\left(\mathrm{mg} \text { sugar } \mathrm{g}^{-1} \mathrm{DW}\right) \\
\text {. }\end{array}$} \\
\hline Upper stem & 2.6 & 1.6 & 2.4 & 1.6 & 2.2 & 2.0 & 0.35 \\
\hline Roots & 2.7 & 1.0 & 2.2 & 1.7 & 1.9 & 1.9 & 0.29 \\
\hline \multicolumn{8}{|c|}{ Starch concentration (mg starch $\left.\mathrm{g}^{-1} \mathrm{DW}\right)$} \\
\hline Upper stem & 2.5 & 1.7 & 2.7 & 1.8 & 2.7 & 2.1 & 0.63 \\
\hline Roots & 1.5 & 1.5 & 2.0 & 1.4 & 2.0 & 2.2 & 0.46 \\
\hline
\end{tabular}


Table 5

Amount of ${ }^{13} \mathrm{C}$ in various plant parts and ${ }^{13} \mathrm{C}$ exported of three pigeonpea genotypes on the third day after feeding with ${ }^{13} \mathrm{CO}$

\begin{tabular}{|c|c|c|c|c|c|c|c|c|}
\hline & \multirow[t]{2}{*}{ Plant part } & \multicolumn{2}{|l|}{ ICPH 8} & \multicolumn{2}{|l|}{ ICPL 87} & \multicolumn{2}{|c|}{ UPAS 120} & \multirow[t]{2}{*}{$\operatorname{LSD}(0.05)$} \\
\hline & & Control & Low $\mathrm{P}$ & Control & Low $\mathrm{P}$ & Control & Low $\mathrm{P}$ & \\
\hline \multirow[t]{6}{*}{${ }^{13} \mathrm{C}$ amount ( $\mu \mathrm{g}$ per plant) } & ${ }^{13} \mathrm{C}$-fed leaf & 254 & 421 & 466 & 172 & 294 & 83 & 187 \\
\hline & Upper leaves & 110 & 211 & 455 & 94 & 276 & 69 & 138 \\
\hline & Upper stem & 108 & 199 & 387 & 96 & 250 & 65 & 118 \\
\hline & Lower leaves and stem & 404 & 481 & 558 & 208 & 343 & 78 & $\mathrm{NS}^{\mathrm{a}}$ \\
\hline & Roots & 86 & 389 & 230 & 381 & 166 & 210 & 259 \\
\hline & Whole plant & 708 & 1280 & 2096 & 952 & 1328 & 504 & 981 \\
\hline${ }^{13} \mathrm{C}$ export $(\%)$ & & 72.8 & 72.6 & 75.4 & 81.5 & 78.1 & 83.3 & 4.7 \\
\hline
\end{tabular}

${ }^{\text {a }}$ NS, not significant.

of the whole plant ${ }^{13} \mathrm{C}$ was partitioned within the leaf, stem and raceme on the node of the ${ }^{13} \mathrm{C}$-fed leaf in both cultivars. Phosphorus deficiency increased the proportion of ${ }^{13} \mathrm{C}$ in the raceme of ICPL 87, but in UPAS 120, the partitioning to the racemes decreased, and more of the material accumulated in the stem and leaves (Fig. 3).

\subsection{3. ${ }^{13}$ C partitioning in various cellular fractions of the} raceme

The low $\mathrm{P}$ treatment decreased the ${ }^{13} \mathrm{C}$ allocation in all the cellular components of the raceme in both cultivars, except in the cellulose fraction of ICPL 87 (Table 7). However, the proportion of ${ }^{13} \mathrm{C}$ distribution in the cellular components

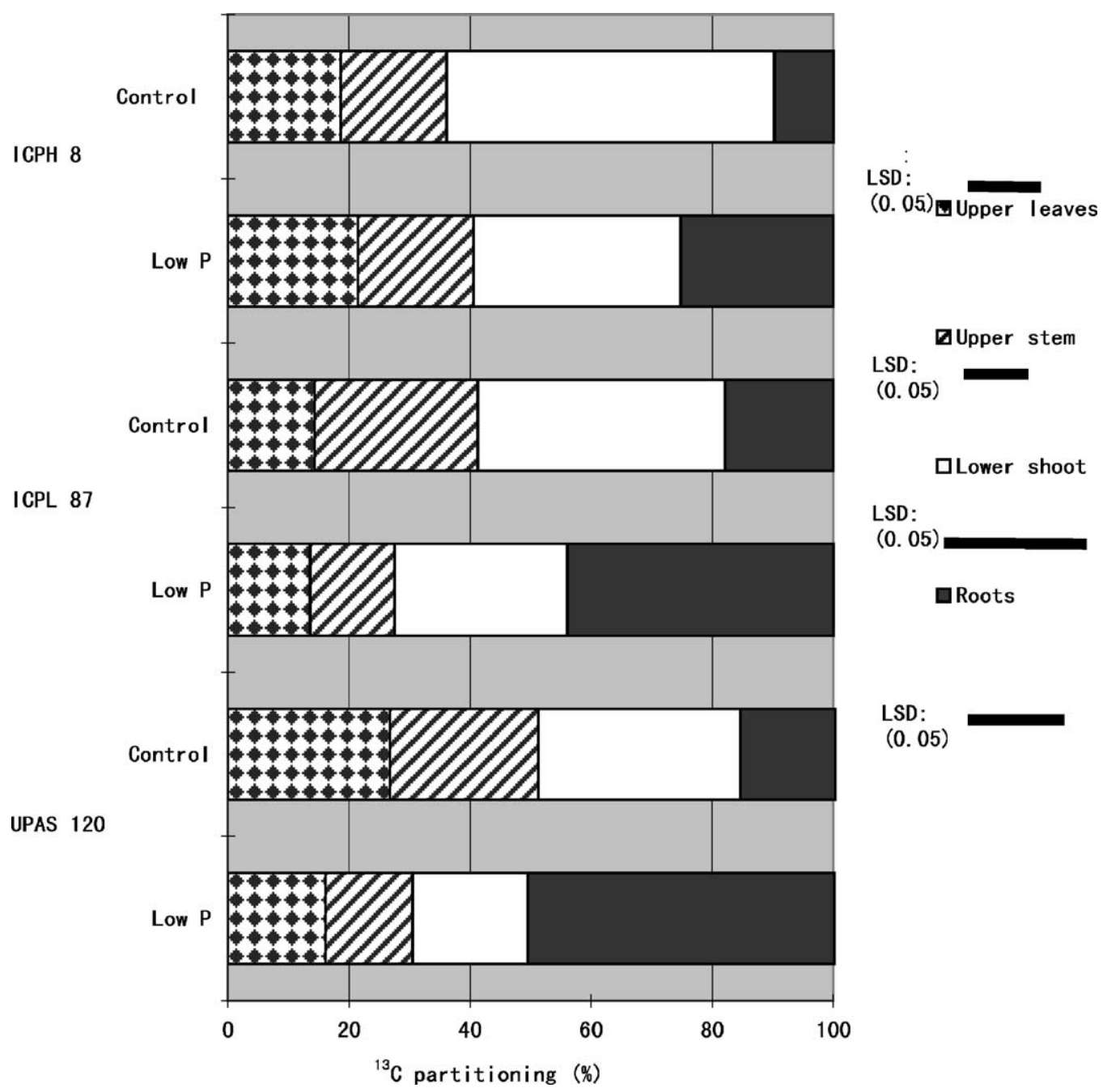

Fig. 2. Effect of $\mathrm{P}$ application levels on partitioning of ${ }^{13} \mathrm{C}$ to various plant parts of pigeonpea cultivars at the vegetative growth stage (Experiment $\mathrm{I}$ ). 


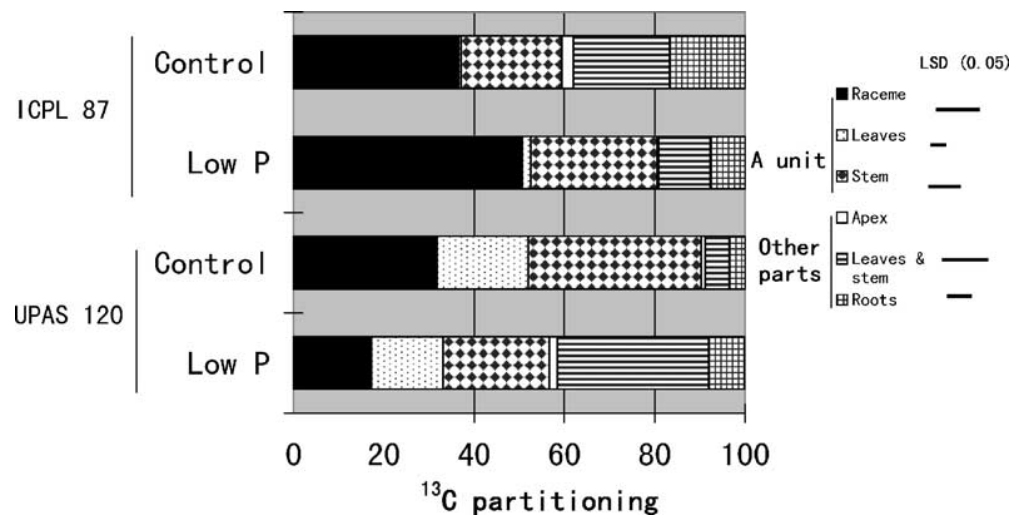

Fig. 3. Effect of $\mathrm{P}$ supply on partitioning of ${ }^{13} \mathrm{C}$ to various plant parts of pigeonpea cultivars, UPAS 120 and ICPL 87 at the stage prior to flowering (Experiment II).

Table 6

Effect of phosphorus treatment on plant biomass, $\mathrm{P}$ concentration and content in the various plant parts of non-hybrid pigeonpea cultivars

\begin{tabular}{|c|c|c|c|c|c|c|c|c|c|c|c|}
\hline & \multicolumn{2}{|c|}{$\begin{array}{l}\text { Dry weight } \\
\text { (g per plant) }\end{array}$} & \multirow[t]{2}{*}{$\begin{array}{l}\text { LSD } \\
(0.05)\end{array}$} & \multicolumn{2}{|c|}{$\begin{array}{l}\text { P concentration } \\
\left(\mathrm{g} \mathrm{kg}^{-1}\right)\end{array}$} & \multirow[t]{2}{*}{$\begin{array}{l}\text { LSD } \\
(0.05)\end{array}$} & \multicolumn{2}{|c|}{$\begin{array}{l}\text { Total P content } \\
\text { (mg P per part) }\end{array}$} & \multirow[t]{2}{*}{$\begin{array}{l}\text { LSD } \\
(0.05)\end{array}$} & \multicolumn{2}{|c|}{$\begin{array}{l}\text { Percent relative to control } \\
(\%)\end{array}$} \\
\hline & Low P & Control & & Low $\mathrm{P}$ & Control & & Low $\mathrm{P}$ & Control & & Dry weight & $\mathrm{P}$ amount \\
\hline \multicolumn{12}{|l|}{ Racemes } \\
\hline UPAS 120 & 0.2 & 0.2 & 0.1 & 2.1 & 3.3 & 1.9 & 0.3 & 0.8 & 0.3 & 67 & 38 \\
\hline ICPL 87 & 0.2 & 0.3 & & 1.9 & 2.1 & & 0.4 & 0.6 & & 65 & 67 \\
\hline \multicolumn{12}{|l|}{ Leaf blades } \\
\hline UPAS 120 & 2.7 & 16.4 & 5.1 & 0.8 & 1.3 & 0.7 & 2.2 & 22.0 & 7.5 & 16 & 10 \\
\hline ICPL 87 & 5.1 & 13.0 & & 1.0 & 1.4 & & 5.2 & 18.4 & & 39 & 28 \\
\hline \multicolumn{12}{|c|}{ Stem and petioles } \\
\hline UPAS 120 & 8.5 & 33.7 & 10.6 & 0.2 & 0.5 & 0.2 & 1.8 & 15.1 & 4.8 & 25 & 12 \\
\hline ICPL 87 & 8.8 & 25.3 & & 0.2 & 0.4 & & 2.9 & 14.4 & & 35 & 20 \\
\hline \multicolumn{12}{|l|}{ Roots } \\
\hline UPAS 120 & 11.1 & 25.0 & 8.8 & 0.3 & 0.6 & 0.4 & 3.3 & 14.1 & 5.4 & 44 & 23 \\
\hline ICPL 87 & 6.9 & 14.8 & & 0.6 & 0.8 & & 3.9 & 11.1 & & 47 & 35 \\
\hline \multicolumn{12}{|l|}{ Whole plant } \\
\hline UPAS 120 & 21.8 & 75.3 & 27.2 & - & - & - & 7.6 & 52.0 & 11.9 & 29 & 15 \\
\hline ICPL 87 & 20.8 & 53.1 & & - & - & - & 12.4 & 44.5 & & 39 & 28 \\
\hline
\end{tabular}

Table 7

Effect of phosphorus treatment on ${ }^{13} \mathrm{C}$ allocation in various fractions of racemes in a source-sink unit of pigeonpea cultivars

\begin{tabular}{|c|c|c|c|c|c|}
\hline \multirow[t]{2}{*}{ Fraction } & \multicolumn{2}{|c|}{ UPAS 120} & \multicolumn{2}{|l|}{ ICPL 87} & \multirow[t]{2}{*}{$\operatorname{LSD}(0.05)$} \\
\hline & Control & Low $\mathrm{P}$ & Control & Low $\mathrm{P}$ & \\
\hline \multicolumn{6}{|l|}{ Cytosol } \\
\hline${ }^{13} \mathrm{C}$ amount ( $\mu \mathrm{g}$ per plant) & 49.1 & 19.0 & 89.3 & 31.5 & 26.1 \\
\hline Proportion of ${ }^{13} \mathrm{C}$ amount (\%) & 34 & 31 & 46 & 35 & \\
\hline \multicolumn{6}{|l|}{ Hemicellulose } \\
\hline${ }^{13} \mathrm{C}$ amount ( $\mu$ g per plant) & 29.8 & 21.1 & 77.5 & 58.9 & $\mathrm{NS}^{\mathrm{a}}$ \\
\hline Proportion of ${ }^{13} \mathrm{C}$ amount $(\%)$ & 20 & 34 & 40 & 50 & \\
\hline \multicolumn{6}{|l|}{ Cellulose } \\
\hline${ }^{13} \mathrm{C}$ amount ( $\mu \mathrm{g}$ per plant) & 67.4 & 21.9 & 26.9 & 28.4 & 24.8 \\
\hline Proportion of ${ }^{13} \mathrm{C}$ amount $(\%)$ & 46 & 35 & 14 & 24 & \\
\hline \multicolumn{6}{|l|}{ Whole racemes } \\
\hline${ }^{13} \mathrm{C}$ amount ( $\mu$ g per plant) & 146.3 & 62.0 & 193.7 & 118.8 & - \\
\hline Proportion of ${ }^{13} \mathrm{C}$ amount $(\%)$ & 100 & 100 & 100 & 100 & \\
\hline
\end{tabular}

Values are the proportion of ${ }^{13} \mathrm{C}$ in individual fractions relative to that in the whole raceme.

a NS, not significant. 
was not similar to that of the total ${ }^{13} \mathrm{C}$ allocation; it increased in the hemicellulose fraction in contrast to the cytosol or cellulose fractions in both cultivars under similar treatment.

\section{Discussion}

The results in the present study that the whole plant weight of pigeonpea was adversely affected by the low $\mathrm{P}$ treatment; the decrease was smallest in cultivar ICPH 8 and largest in UPAS 120 are indicative of tolerance of P deficiency in the improved hybrid cultivar compared with the non-hybrids. These results also agree with the observations of Adu-Gyamfi et al. [3], who found that the response to low $\mathrm{P}$ application in terms of biomass production varies among pigeonpea cultivars. The current results and our earlier work [3] together substantiate that plant biomass can be influenced by the amount of $\mathrm{P}$ accumulated in the plant. However, biomass accumulation had no relationship with P-utilization efficiency [18]. This evidence suggests that the improved cultivar ICPH 8 is capable of larger biomass production at low P mainly because of its higher P-absorption ability, rather than a greater P-utilization efficiency. In the present experiment, the greater uptake of $\mathrm{P}$ by the ICPH 8 cultivar was not only due to specific high P-absorption ability, but also to a larger root weight in comparison to the non-hybrid cultivars. Recent studies have revealed the presence of multiple genes encoding phosphate transporters involved in $\mathrm{P}$ uptake and emphasized the need to control their spatial and temporal expression for adaptation of plants to fluctuating environment [19]. In view of these developments, it is necessary to compare the structural and functional differences between the phosphate transporters of the pigeonpea genotypes possessing contrasting P-uptake capacity.

In addition to the variation in P-absorption ability, genotypic difference in response to $\mathrm{P}$ deficiency may be related to the magnitude of resistance of the cultivar to a decrease in source activities, which are a function of leaf area and photosynthetic rate. The results of the present work indicate that the reduction in total leaf area in low P-treated plants was due to decreases in leaf number and average leaf area; the hybrid variety was less affected by the stress than the non-hybrids. This is consistent with the reports that leaf initiation [20,21], leaf number and leaf area [18] are sensitive to low $\mathrm{P}$ conditions. Compared with the effect on leaf number, the response to low $\mathrm{P}$ supply of photosynthetic rate of the pigeonpea genotypes was not as noticeable, although it was significant. However, resistance to low P supply among the cultivars cannot simply be attributed to the difference in source activity alone. At low P supply, the number of leaves declined, because the stress affected leaf initiation. In other words, the reduction of source activity, which occurred at low $\mathrm{P}$ was primarily a consequence of the effect of the stress on sink activity. A similar observation was reported in sugar beet (Beta vulgaris L.), where low P restricted growth of the shoot and expansion of the leaves, but had only a minor effect on production of photosynthate per unit leaf area [22].

The ${ }^{13} \mathrm{C}$-tracer experiment revealed that the ${ }^{13} \mathrm{C}$ amount (Table 5) and the proportion of whole-plant ${ }^{13} \mathrm{C}$ (Fig. 2) in roots increased at low $\mathrm{P}$ supply in contrast to the stem and upper leaves in all the cultivars. However, this tendency was more pronounced in the non-hybrids than in the hybrid cultivar. Since P is a major essential element, plant growth is restricted at suboptimal supply [19] and preference is given to growth of those organs important for survival. In addition to our work on pigeonpea, there are reports in sugar beet (B. vulgaris L.) [23], bean (Phaseolus vulgaris L.) [24] and maize (Zea mays L.) $[25,26]$ which reveal that shoot growth is restricted and more photosynthate is transported to roots for better maintained growth of the root under limiting supply of P. Under such a situation, a cultivar less susceptible to $P$ deficiency can partition more assimilates for shoot growth and grain yield than a sensitive cultivar, where partitioning to roots is more important for survival. In the present experiment, the hybrid cultivar ICPH 8 performed better at low P supply than the non-hybrids ICPL 87 and UPAS 120, because of its capacity for greater partitioning of assimilates in favor of shoot growth than root growth mainly due to uptake of more phosphorus. An increase in root to shoot ratio is considered important for tolerance of low $\mathrm{P}$ stress in plants [13], but this strategy is not suitable for plants containing economically beneficial parts in the shoot.

This assumption on root to shoot ratio as a criterion for tolerance to $P$ stress is further supported by the variation that existed between cultivars in carbohydrate concentrations of stem and roots in response to low P (Table 4). The sugar and starch concentrations of the plant parts mostly declined at low $\mathrm{P}$ in the ICPH 8 and ICPL 87 cultivars, but not so in the sensitive cultivar UPAS 120 . In UPAS 120 , the carbohydrate concentration increased marginally in roots, while it decreased in the upper stem in response to low P supply. At low levels of $\mathrm{N}$ and $\mathrm{P}$, plants usually reduce investment in shoot biomass [27]. The decrease in starch accumulation in the upper stem at low $\mathrm{P}$ in the present experiment supports this report and the observation is similar to that in tomato (Lycopersicon esculentum Mill.) [18]. Among the cultivars, UPAS 120 can be considered more sensitive to low $\mathrm{P}$, because it partitioned more carbohydrates to the roots. In addition to this, a sensitive cultivar partitions less photosynthetic assimilates to the reproductive sink compared with a resistant cultivar, as shown by the comparison of ${ }^{13} \mathrm{C}$ partitioning from the ${ }^{13} \mathrm{C}$-fed leaf to the raceme of UPAS 120 and ICPL 87 (Fig. 3). Thus, a resistant genotype gives preference to partitioning of assimilates to the reproductive sink and maintains its growth at low $\mathrm{P}$.

The incorporation of ${ }^{13} \mathrm{C}$ into various fractions of the cellular components provides some insight into the factors restricting sink activity of the raceme under low $\mathrm{P}$ conditions. At low $\mathrm{P}$ supply the proportion of ${ }^{13} \mathrm{C}$ incorporation in cytosol and hemicellulose fractions decreased and increased, 
respectively, in both ICPL 87 and UPAS 120 (Table 7). However, the proportion of ${ }^{13} \mathrm{C}$ incorporation into the cellulose fraction declined at low P in UPAS 120 in contrast to that of ICPL 87. With this evidence, it is assumed differences in cellulose biosynthesis at low $\mathrm{P}$ among pigeon cultivars can influence sink activity of raceme. Further, the tolerance of cellulose synthesis to $\mathrm{P}$ deficiency may partially govern the tolerance of sink parts like raceme to low P. A similar result was obtained in marshbean (Vigna aconitifolia), in which the cell wall weight in developing leaves declined in parallel to the decrease in P content at low P [28]. In conclusion, it is assumed that low $\mathrm{P}$ application primarily impairs cellulose synthesis in meristematic sinks, and the subsequent reductions in source activity and biomass yield are consequences of this effect; although a direct effect of low $\mathrm{P}$ on the source is not ruled out.

\section{References}

[1] S. Ogata, J. Adu-Gyamfi, K. Fujita, The effect of phosphorus and $\mathrm{pH}$ on dry matter production, dinitrogen fixation and critical phosphorus concentration in pigeon pea (Cajanus cajan L. Millesp), Soil Sci. Plant Nutr. 34 (1988) 55-64.

[2] J.J. Adu-Gyamfi, K. Fujita, S. Ogata, Phosphorus fractions in relation to growth in pigeon pea (Cajanus cajan (L) Millsp.) at various levels of P supply, Soil Sci. Plant Nutr. 36 (1990) 531-543.

[3] J.J. Adu-Gyamfi, K. Fujita, S. Ogata, Phosphorus absorption and utilisation efficiency of pigeon pea (Cajanus cajan L. Millsp.) in relation to dry matter production, and dinitrogen fixation, Plant Soil 119 (1989) 315-324.

[4] A.L. Fredeen, I.M. Rao, N. Terry, Influence of phosphorus nutrition on growth and carbon partitioning in Glycine max, Plant Physiol. 89 (1989) 225-230.

[5] J. Jacob, D.W. Lawlor, Dependence of photosynthesis of sunflower and maize on phosphate supply, ribulose-1,5-biphosphate carboxylase/oxygenase activity, and ribulose-1,5-biphosphate pool size, Plant Physiol. 98 (1992) 801-807.

[6] A.J. Pieters, M.J. Paul, D.W. Lawlor, Low sink demand limits photosynthesis under Pi deficiency, J. Exp. Bot. 52 (2001) 1083-1091.

[7] R.C. Leegood, Primary photosynthate production: physiology and metabolism, in: E. Zamski, R.A. Schaffer (Eds.), Photoassimilate Distribution in Plants and Crops Source Sink Relationships, Marcel Dekker, New York, 1996, pp. 21-41.

[8] J. Koâmann, B. Muller-Rober, J.W. Riesmeier, L. Willmitzer, Potential for modifying source-sink interactions through the genetic manipulation of carbohydrate metabolism, in: E. Zamski, R.A. Schaffer (Eds.), Photoassimilate Distribution in Plants and Crops Source Sink Relationships, Marcel Dekker, New York, 1996, pp. 369-387.

[9] T.H. Nielsen, A. Krapp, U. Roper-Scwarz, M. Stitt, The sugar mediated regulation encoding the small sub-unit of Rubisco and the regulatory subunit of ADP glucose pyrophosphorylase is modified by phosphate and nitrogen, Plant Cell Environ. 21 (1998) 443-454.

[10] J. Chiera, J. Thomas, T. Rufty, Leaf initiation and development in soybean under phosphorus stress, J. Exp. Bot. 53 (2002) 473-481.
[11] W.D. Jeschke, A.D. Peuke, J.S. Pate, W. Hartung, Transport synthesis and catabolism of abscisic acid (ABA) in intact plants of castor bean (Ricinus communis L.) under phosphate deficiency and moderate salinity, J. Exp. Bot. 48 (1997) 1737-1747.

[12] W.D. Jeschke, E. Kirkby, A. Peuke, J.S. Pate, W. Hartung, Effect of $\mathrm{P}$ deficiency on assimilation and transport of nitrate and phosphate in intact plants of castor bean (Ricinus communis L.), J. Exp. Bot. 48 (1997) 75-91.

[13] M. Halsted, J. Lynch, Phosphorus responses in $\mathrm{C}_{3}$ and $\mathrm{C}_{4}$ species, J. Exp. Bot. 47 (1996) 497-505.

[14] Y.S. Chauhan, C. Johansen, K.B. Saxena, Physiological basis of yield in short duration pigeonpea grown in different environments of the semi-arid tropics, J. Agron. Crop Sci. 174 (1995) 163-171.

[15] E.W. Yemm, A.J. Willis, The estimation of carbohydrates in plant extracts by anthrone, Biochem. J. 57 (1954) 508-514.

[16] O. Sawada, J. Ito, K. Fujita, Characteristics of photosynthesis and translocation of ${ }^{13} \mathrm{C}$-labelled photosynthate in husk leaves of sweet corn, Crop Sci. 35 (1995) 480-485.

[17] N. Sakurai, S. Tanaka, S. Kuraishi, Changes in wall polysaccharides of squash (Cucurbita maxima Duch.) hypocotyls under water stress condition. 1. Wall sugar composition and growth as affected by water stress, Plant Cell Physiol. 28 (1987) 1051-1058.

[18] C.C. De Groot, L.F.M. Marcelis, R. Van Dew Boogaard, H. Lambers, Growth and dry-mass partitioning in tomato as affected by phosphorus nutrition and light, Plant Cell Environ. 24 (2001) 13091317.

[19] D.P. Schatchtman, R.J. Reid, S.M. Ayling, Phosphorus uptake by plants: from soil to cell, Plant Physiol. 116 (1998) 447-453.

[20] J. Lynch, L. Andre, E. Epstein, Vegetative growth of common bean in response to phosphorus nutrition, Crop Sci. 31 (1991) 380387.

[21] D. Plenet, S. Etchebest, A. Mollier, S. Pellerin, Growth analysis of maize field crops under phosphorus deficiency, Plant Soil. 223 (2000) 117-130.

[22] I.M. Rao, A.L. Fredeen, N. Terry, Leaf phosphate status, photosynthesis and carbon partitioning in sugar beet. III. Diurnal changes in carbon partitioning and carbon export, Plant Physiol. 92 (1990) $29-36$.

[23] I.M. Rao, N. Terry, Leaf phosphate status, photosynthesis, and carbon partitioning in sugar beet. IV. Changes with time following increased supply of phosphate to low-phosphate plants, Plant Physiol. 107 (1995) 1313-1321.

[24] A.M. Rychter, D.D. Randall, The effect of phosphate deficiency on carbohydrate metabolism in bean roots, Physiol. Plant. 91 (1994) 383-388.

[25] A. Mollier, S. Pellerin, Maize root system growth and development as influenced by phosphorus deficiency, J. Exp. Bot. 50 (1999) 487497.

[26] S. Pellerin, A. Mollier, D. Plenet, Phosphorus deficiency affects the rate of emergence and number of maize adventitious nodal roots, Agron. J. 92 (2000) 690-697.

[27] D. Meziane, B. Shipley, Interacting determinants of specific leaf area in 22 herbaceous species: effects of irradiance and nutrient availability, Plant Cell Environ. 22 (1999) 447-459.

[28] M.I. Chaudhary, H. Saneoka, K. Fujita, Relationship between cell wall composition and leaf development in low P marshbean (Vigna aconitifolia) plants, in: T. Ando et al. (Eds.), Plant Nutrition for Sustainable Food Production and Environment, Kluwer Academic Publishers, Dordrecht, 1997, pp. 91-92. 